\title{
TABLE OF LEGISLATION AND OFFICIAL DOCUMENTS
}

\section{Regulations}

Regulation (EEC) No 1017/68 of the Council of 19 July 1968 applying rules of competition to transport by rail, road and inland waterway, OJ L 175 , 23.7 .1968 , p. $1-12 \ldots 5.32,5.37$

Council Regulation (EEC) No 954/79 of 15 May 1979 concerning the ratification by Member States of, or their accession to, the United Nations Convention on a Code of Conduct for Liner Conferences, OJ L 121, 17.5.1979, p. 1-4

8.1299

Council Regulation (EEC) No 4056/86 of 22 December 1986 laying down detailed rules for the application of Articles 85 and 86 of the Treaty to maritime transport, OJ L 378, 31.12.1986, p. 4-13

$5.32,5.37$

Council Regulation (EEC) No 3975/87 of 14 December 1987 laying down the procedure for the application of the rules on competition to undertakings in the air transport sector, OJ L $374,31.12 .1987$, p.1-8

$5.32,5.37$

Council Regulation (EEC) No 4064/89 of 21 December 1989 on the control of concentra- tions between undertakings (Old Merger Regulation) OJ L $395,30.12 .1989$, p. $1-12$ (republished in OJ L 257/90 P 13) (Old EU Merger Regulation), [1989] OJ L 395, 30.12.1989... $1.1,1.40,4.29,4.36,4.461$, 4.567, 5.37, 8.1118 Commission Regulation (EEC) No $2367 / 90$ of 25 July 1990 on the notifications, time limits and hearings provided for in Council Regulation (EEC) No 4064/89 on the control of concentrations between undertakings, OJ L 219, 14.8.1990, p. 5-25[1990] OJ 1990 L 219. 1.111

Commission Regulation (EC) No 3384/94 of 21 December 1994 on the notifications, time limits and hearings provided for in Council Regulation (EEC) No 4064/89 on the control of concentrations between undertakings, OJ L 377, 31.12.1994, p. 1-27 [1994] OJ L 377, 31.12.1994_............................5.37

Commission Regulation (EC) No 870/95 of 20 April 1995 on the application of Article 85 (3) of the Treaty to certain categories of agreements, decisions and concerted practices 
between liner shipping companies (consortia) pursuant to Council Regulation (EEC) No 479/92 (Consortia Block Exemption Regulation), OJ L 89, 21.4.1995, p. 7-14[1995].

8.1303

Council Regulation (EC) No 1310/97 of 30 June 1997 amending Regulation (EEC) No 4064/89 on the control of concentrations between undertakings, OJ L 180, 9.7.1997, p. 1-6 OJ 1997 L 180 1.68 , $1.109,4.569$

Commission Regulation (EC) No $447 / 98$ of 1 March 1998 on the notifications, time limits and hearings provided for in Council Regulation (EEC) No 4064/89 on the control of concentrations between undertakings, OJ L 61, 2.3.1998, p. $1-28$ 4.75

Commission Regulation (EC) No 823/2000 of 19 April 2000 on the application of Article 81(3) of the Treaty to certain categories of agreements, decisions and concerted practices between liner shipping companies (Consortia Block Exemption Regulation), OJ L 100, 20.4.2000, p. 24-30 ......8.1303

Regulation 1049/2001/EC of the European Parliament and of the Council of 30 May 2001 regarding public access to European Parliament, Council and Commission documents (Transpar- ency Regulation), [2001], OJ L 145, 31.5.2001, p. 43-48 6.162

Council Regulation (EC) No 1/2003 of 16 December 2002 on the implementation of the rules on competition laid down in Articles 81 and 82 of the Treaty, OJ L 1, 4.1.2003, p. 1-25 .......5.32, $5.37,6.151,7.26$

Regulation 1228/2003/EC of the European Parliament and of the Council of 26 June 2003 on conditions for access to the network for cross-border exchanges in electricity, [2003] OJ L 176, 15.7.2003, p. 1-10...

8.877

Regulation 139/2004/EC of 20 January 2004 on the control of concentrations between undertakings (EC Merger Regulation), [2004] OJ L 24, 29.01.2004, p. $1-22 \ldots . .1 .1,1.82,2.267,2.346$, $4.31,4.475,4.590,6.151$, $6.162,6.1637 .1,10.6,10.24$ Regulation 139/2004/EC on the Control of concentrations between undertakings, [2004] OJ 2004 L 133/1 .........1.109, 1.116

Council Regulation (EC) No 411/2004 of 26 February 2004 repealing Regulation (EEC) No 3975/87 and amending Regulations (EEC) No 3976/87 and (EC) No 1/2003, in connection with air transport between the Community and third countries, OJ L 68, 6.3.2004, p. $1-2 \ldots . . . .5 .32,5.37$ 
Commission Regulation (EC) No 611/2005 of 20 April 2005 amending Regulation (EC) No $823 / 2000$ on the application of Article 81(3) of the Treaty to certain categories of agreements, decisions and concerted practices between liner shipping companies (Consortia Block Exemption Regulation), OJ L 101, 21.4.2005, p. 10-11

8.1303

Commission Regulation (EC) No 773/2004 of 7 April 2004 relating to the conduct of proceedings by the Commission pursuant to Articles 81 and 82 of the EC Treaty, OJ L 123, 27.4.2004, p. 18-24 .......6.151, 7.267

Commission Regulation (EC) No 802/2004 of 7 April 2004 implementing Council Regulation (EC) No 139/2004 on the control of concentrations between undertakings, OJ L 133, 30.4.2004, p. 1-39.

$$
\text { 1.82, 1.111, 2.297, 2.335, }
$$$$
4.75,4.716,6.62,6.151
$$

Council Regulation (EC) No $1419 / 2006$ of 25 September 2006 repealing Regulation (EEC) No 4056/86 laying down detailed rules for the application of Articles 85 and 86 of the Treaty to maritime transport, and amending Regulation (EC) No $1 / 2003$ as regards the extension of its scope to include cabotage and interna- tional tramp services, OJ L 269, 28.9.2006, p. 1-3 .... 5.32, 5.37,

8.1302

Commission Regulation (EC) No $1033 / 2008$ of 20 October 2008 amending Regulation (EC) No 802/2004 implementing Council Regulation (EC) No 139/2004 on the control of concentrations between undertakings, OJ L 279, 22.10.2008, p. 3-12 ........ 1.111

Council Regulation (EC) No 169/2009 of 26 February 2009 applying rules of competition to transport by rail, road and inland waterway, OJ L 61, 5.3.2009, p. 1-5........ 5.32, 5.37 Regulation (EC) No 713/2009 of the European Parliament and of the Council of 13 July 2009 establishing an Agency for the Cooperation of Energy Regulators ("ACER Regulation"), OJ L 211, 14.8.2009, p. 1-14 ..

8.879

Regulation (EC) No 714/2009 of the European Parliament and of the Council of 13 July 2009 on conditions for access to the network for cross-border exchanges in electricity and repealing Regulation (EC) No 1228/2003 ("Electricity Regulation”), OJ L 211, 14.8.2009, p. $15-35$ 8.879

Regulation (EC) No 715/2009 of the European Parliament and of the Council of 13 July 2009 on conditions for access to the nat- 
ural gas transmission networks and repealing Regulation (EC) No 1775/2005 ("Gas Regulation”), OJ L 211, 14.8.2009, p. 36-54, 8.879

Commission Regulation (EC) No 906/2009 of 28 September 2009 on the application of Article 81(3) of the Treaty to certain categories of agreements, decisions and concerted practices between liner shipping companies (Consortia Block Exemption), OJ L 256, 29.9.2009, p. 31-34 ......8.1303

Commission Regulation (EU) No $330 / 2010$ of 20 April 2010 on the application of Article 101(3) of the Treaty on the Functioning of the European Union to categories of vertical agreements and concerted practices ("Vertical Block Exemption Regulation"), OJ L 102, 23.4.2010, p. 1-7 .... 4.291

Regulation (EU) No 1227/2011 of the European Parliament and of the Council of 25 October 2011 on wholesale energy market integrity and transparency ("REMIT66"), OJ L 326, 8.12.2011, p. 1-16........... 8.912

Regulation (EU) No 531/2012 of the European Parliament and of the Council of 13 June 2012 on roaming on public mobile communications networks within the Union, OJ L 172, 30.6.2012, p. 10-35 ........ 8.315

Commission Implementing Regula- tion (EU) No 1269/2013 of 5 December 2013 amending Regulation (EC) No 802/2004 implementing Council Regulation (EC) No 139/2004 on the control of concentrations between undertakings ("Implementing Regulation”, OJ L 336, 14.12.2013, p. 1-36 ........ 1.112

Regulation (EU) No 596/2014 of the European Parliament and of the Council of 16 April 2014 on market abuse (market abuse regulation), OJ L 173, 12.6.2014, p. 1-61 8.912

Commission Regulation (EU) No $697 / 2014$ of 24 June 2014 amending Regulation (EC) No 906/2009 as regards its period of application, OJ L 184, 25.6.2014, p. 3-3 ............8.1303

Council Regulation (EU) 2015/1589 of 13 July 2015 laying down detailed rules for the application of Article 108 of the Treaty on the Functioning of the European Union, OJ L 248, 24.9.2015, p. 9-29 7.267

Regulation (EU, Euratom) 2015/2422 of the European Parliament and of the Council of 16 December 2015 amending Protocol No 3 on the Statute of the Court of Justice of the European Union, OJ L 341, 24.12.2015, p. 14-17 ........9.10, $9.12,9.242$ Regulation (EU) 2019/452 of the European Parliament and of the Council of 19 March 2019 es- 
tablishing a framework for the screening of foreign direct investments into the Union, OJ L 79I , 21.3.2019, p. 1-14 ...1.11, $2.352,7.236$

Regulation (EU) 2019/941 of the European Parliament and of the Council of 5 June 2019 on riskpreparedness in the electricity sector, OJ L 158, 14.6.2019, p. $1-21$ 8.881

Regulation (EU) 2019/942 of the European Parliament and of the Council of 5 June 2019 establishing a European Union Agency for the Cooperation of Energy Regulators, OJ L 158, 14.6.2019, p. 22-53 8.881 Regulation (EU) 2019/943 of the European Parliament and of the Council of 5 June 2019 on the internal market for electricity, OJ L 158, 14.6.2019, p. 54124 8.881

Commission Regulation (EU) 2020/436 of 24 March 2020 amending Regulation (EC) No 906/2009 as regards its period of application, OJ L 90, 25.3.2020, p. 1-2 ...........8.1303

\section{Directives}

Fourth Council Directive 78/660/ EEC of 25 July 1978 based on Article 54 (3) (g) of the Treaty on the annual accounts of certain types of companies, OJ L 222, 14.8.1978, p. 11-31

2.130
Council Directive $86 / 635 /$ EEC of 8 December 1986 on the annual accounts and consolidated accounts of banks and other financial institutions, OJ L 372, 31.12.1986, p. 1-17 ........ 2.255

Council Directive 91/440/EEC of 29 July 1991 on the development of the Community's railways, OJ L 237, 24.8.1991, p. 25-28

$8.1241,8.1292,8.1442$

Council Directive 95/18/EC of 19 June 1995 on the licensing of railway undertakings, OJ L $143,27.6 .1995$, p. $70-74$

$8.252,8.1241$

Directive 96/92/EC of the European Parliament and of the Council of 19 December 1996 concerning common rules for the internal market in electricity, OJ L $27,30.1 .1997$, p. $20-29 . .8 .874$ Directive 98/30/EC of the European Parliament and of the Council of 22 June 1998 concerning common rules for the internal market in natural gas, OJ L 204, 21.7.1998, p. 1-12.8.874

Directive 2001/14/EC of the European Parliament and of the Council of 26 February 2001 on the allocation of railway infrastructure capacity and the levying of charges for the use of railway infrastructure and safety certification ("First Railway Package”), OJ L 75, 15.3.2001, p. 29-46. 8.1442 
Directive 2002/21/EC of the European Parliament and of the Council of 7 March 2002 on a common regulatory framework for electronic communications networks and services (Framework Directive), OJ L $108,24.4 .2002$, p. 33-50

$8.196,8.235,8.236$, $8.252,8.310,8.286$

Directive 2003/54/EC of the European Parliament and of the Council of 26 June 2003 concerning common rules for the internal market in electricity, OJ L 176, 15.7.2003, p. 37-56 8.875

Directive 2003/55/EC of the European Parliament and of the Council of 26 June 2003 concerning common rules for the internal market in natural gas, OJ L 176, 15.7.2003, p. 57-78 9.164

Directive 2009/28/EC of the European Parliament and of the Council of 23 April 2009 on the promotion of the use of energy from renewable sources ("Renewable Electricity Directive), OJ L 140, 5.6.2009, p. $16-62$ 8.913

Directive 2009/72/EC of the European Parliament and of the Council of 13 July 2009 concerning common rules for the internal market in electricity, OJ L 211, 14.8.2009, p. 55-93 ….... 8.879, 8.1013

Directive 2009/73/EC of the European Parliament and of the
Council of 13 July 2009 concerning common rules for the internal market in natural gas, OJ L 211, 14.8.2009, p. 94136 8.879

Directive 2009/138/EC of the European Parliament and of the Council of 25 November 2009 on the taking-up and pursuit of the business of Insurance and Reinsurance (Solvency II), OJ L 335, 17.12.2009, p. 1-155..8.15 Directive 2009/140/EC of the European Parliament and of the Council of 25 November 2009 on a common regulatory framework for electronic communications networks and services, OJ L 337, 18.12.2009, p. 37-69 ..8.195, 8.235

Directive 2012/34/EU of the European Parliament and of the Council of 21 November 2012 establishing a single European railway area, OJ L 343, 14.12.2012, p. 32-77 .....8.1442 Directive 2013/34/EU of the European Parliament and of the Council of 26 June 2013 on the annual financial statements, consolidated financial statements and related reports of certain types of undertakings, OJ L 182, 29.6.2013, p. 19-76

2.130

Directive 2013/36/EU of the European Parliament and of the Council of 26 June 2013 on access to the activity of credit institutions and the prudential super- 
vision of credit institutions and investment firms [2013], OJ L $176,27.6 .2013$, p. $338-436$

$2.254,8.15$

Directive 2014/59/EU of the European Parliament and of the Council of 15 May 2014 establishing a framework for the recovery and resolution of credit institutions and investment firm (BRRD), OJ L 173, 12.6.2014, p. 190-348

8.23

Directive (EU) 2016/797 of the European Parliament and of the Council of 11 May 2016 on the interoperability of the rail system within the European Union (Fourth Railway Package). OJ L 138, 26.5.2016, p. 44-101 8.1244

Directive (EU) 2016/797 of the European Parliament and of the Council of 11 May 2016 on the interoperability of the rail system within the European Union (Fourth Railway Package), OJ L 138, 26.5.2016, p. 44-101 8.1244

Directive (EU) 2016/2370 of the European Parliament and of the Council of 14 December 2016 amending Directive 2012/34/ EU as regards the opening of the market for domestic passenger transport services by rail and the governance of the railway infrastructure (Fourth Railway Package), OJ L 352, 23.12.2016, p. 1-17 .......8.1244
Directive 2017/1132/EU of the European Parliament and of the Council of 14 June 2017 relating to certain aspects of company law [2017], OJ L 169, 30.6.2017, p. 46-127 ........6.75, 6.205

Directive 2018/1972/EU of the European Parliament and of the Council of 11 December 2018 establishing the European Electronic Communications Code, OJ L 321, 17.12.2018, p. 36214 $8.196,8.235$

Directive 2019/944/EU of the European Parliament and of the Council of 5 June 2019 on common rules for the internal market for electricity, [2019] OJ L $158,14.6 .2019$, p. 125199 8.881

\section{Commission Notices}

Commission Notice on the definition of the relevant market for the purposes of Community competition law [1997], OJ C 372, 9.12.1997, p. 5-13 ..........1.116, 8.136

Commission Notice on the concept of full-function joint ventures under Council Regulation $4064 / 89 /$ EEC on the control of concentrations between undertakings [1998] OJ C 66, 2.3.1998, p. 1-4................ 1.116

Commission Notice on calculation of turnover under Council Regulation $4064 / 89 / \mathrm{EEC}$ on the con- 
trol of concentrations between undertakings, [1998] OJ C 66, 2.3.1998, p. 25-35 ............. 1.116 Commission Notice on the concept of a concentration under Council Regulation 4064/89/EEC, [1998] OJ C 66, 2.3.1998, p. 25-35 $1.116,2.16$

Commission Notice on a simplified procedure for treatment of certain concentrations under Council Regulation (EEC) No 4064/89, OJ C 217, 29.7.2000, p. $32-34$

$1.9,5.39,6.122$

Commission Notice on remedies acceptable under Council Regulation 4064/89/EEC and under Commission Regulation 447/98/EC, [2001] OJ C 68, 2.3.2001, p. 3-11 1.116 , $4.571,10.58$

Commission Notice on restrictions directly related and necessary to concentrations, [2001] OJ C 188, 4.7.2001, p. 5-11...5.40

Draft Commission Notice on the appraisal of horizontal mergers under the Council Regulation on the control of concentrations between undertakings, OJ C 331, 31.12.2002, p. 18-31 1.81

Commission Notice on case referral in respect of concentrations, [2004], OJ C 56, 5.3.2005, p. 2-23 $1.116,2.16$

Commission Notice on a simplified procedure for treatment of certain concentrations under Council Regulation
139/2004/EC, [2005] OJ C $366,14.12 .2013$, p. 5-9

$1.9,1.116,6.122$

Commission Notice on the rules for access to the Commission fi le in cases pursuant to Articles 81 and 82 of the EC Treaty, Articles 53, 54 and 57 of the EEA Agreement and Council Regulation 139/2004/EC, [2005], OJ C 325, 22.12.2005, p. 7-15 $1.97,1.116,6.149$

Commission Notice on restrictions directly related and necessary to concentrations, [2005] OJ C 56, 5.3.2005, p. 24-31........... 1.116

Commission Notice on remedies acceptable under Council Regulation 139/2004/EC and under Commission Regulation 802/2004/EC (Remedies Notice), [2008] OJ C 267, 22.10.2008, p. 1-27 ...........1.97, $1.116,4.75,4.571,7.37$

Commission Consolidated Jurisdictional Notice under Council Regulation (EC) No 139/2004 on the control of concentrations between undertakings, OJ C 95, 16.4.2008, p. 1-48.... $1.116,2.257,4.567$

Commission Notice on a simplified procedure for treatment of certain concentrations under Council Regulation 139/2004/EC (Simplified Procedure Notice), [2013], OJ C $366,14.12 .2013$, p. 5-9

$1.9,1.97,1.116,4.20,6.122$ 


\section{Guidelines}

Guidelines on the assessment of horizontal mergers under the Council Regulation on the control of concentrations between undertakings (Horizontal Merger Guidelines), [2004] OJ C 31, 5.2.2004, p. 5-18....... $1.82,1.85,1.116,3.55,3.213$, 4.5, 4.6, 4.30, 4.75, 4.124, 8.132, 8.592, 8.619, 8.1083,

$8.1198,8.1278$

Guidelines on the assessment of non-horizontal mergers under the Council Regulation $139 / 2004 / \mathrm{EC}$ on the control of concentrations between undertakings (Non-Horizontal Merger Guidelines), [2008] OJ C $265,18.10 .2008$, p. 6-25...... $1.85,1.116,4.5,4.6,4.20,4.30$, $4.41,4.75,4.125,8.611,8.652$

Guidelines on the applicability of Article 101 of the Treaty on the Functioning of the European Union to horizontal co-operation agreements, OJ C 11, 14.1.2011, p. 1-72.........8.1302

\section{Communications}

Communication from the Commission - Unbundled access to the local loop: enabling the competitive provision of a full range of electronic communication services, including broadband multimedia and high-speed Internet, OJ C 272, 23.09.2000, p. $55-66$

Communication from the Commission - Inquiry pursuant to $\mathrm{Ar}$ ticle 17 of Regulation 1/2003/ EC into the European gas and electricity sectors, [2006] $\mathrm{COM} / 2006 / 851 . .8 .878,8.981$

Communication from the Commission on the consequences of the Court judgements of 5 November 2002 for the European air transport policy, [2006] $\mathrm{COM} / 2002 / 649$ 8.1129

Communication from the Commission to the Council - Report on the functioning of Regulation 139/2004/EC, [2009] $\mathrm{COM} / 2009 / 0281$..............1.88, $2.201,2.271$ 
Christopher Jones and Lisa Weinert - 9781802203462 Downloaded from PubFactory at 04/26/2023 10:22:33AM 